\title{
Effect of Moistube and subsurface drip irrigation on cowpea (Vigna unguiculata (1.) Walp) production in South Africa
}

\author{
Edwin Kimutai Kanda',3, Aidan Senzanje ${ }^{1}$ and Tafadzwanashe Mabhaudhi ${ }^{2}$ \\ 'School of Engineering, University of KwaZulu-Natal, P. Bag X01, Scottsville, Pietermaritzburg, South Africa \\ ${ }^{2}$ Centre for Transformative Agricultural and Food Systems, School of Agricultural, Earth and Environmental Sciences, University of \\ KwaZulu-Natal, P. Bag X01, Scottsville, 3209, Pietermaritzburg, South Africa \\ ${ }^{3}$ Department of Civil and Structural Engineering, Masinde Muliro University of Science and Technology, PO Box 190, Kakamega, 50100, \\ Kenya
}

Moistube irrigation (MTI) is a new subsurface irrigation technology where the water emits from a semipermeable membrane at a slow rate depending on applied pressure and soil water potential. There is lack of information on how various crops respond to MTI. This study determined growth, yield and water use efficiency (WUE) of cowpea (Vigna unguiculata (L.) Walp) under varying water regimes under MTI and subsurface drip irrigation (SDI), using field and glasshouse experiments in summer and winter of 2018 , respectively. A splitplot design arranged in randomized complete blocks, replicated 3 times, with SDI as the control experiment was used. The main plot was irrigation type while the sub-plots were the water regimes. The water treatments consisted of full irrigation (100\% of crop water requirement $\left(\mathrm{ET}_{\mathrm{c}}\right)$ ), and deficit irrigation (DI) of $70 \% \mathrm{ET}_{c}$ and $40 \% \mathrm{ET}_{c}$. Water deficit had a significant effect $(p<0.05)$ on time to flowering; plants under $40 \% \mathrm{ET}_{c}$ flowered 14 days earlier than plants at $100 \% \mathrm{ET}_{c^{\prime}}$. There were significant $(p<0.05)$ differences in yield components. Grain yields were $1280 \mathrm{~kg} \cdot \mathrm{ha}^{-1}, 2401 \mathrm{~kg} \cdot \mathrm{ha}^{-1}$ and $3189 \mathrm{~kg} \cdot \mathrm{ha}^{-1}$ for $40 \% \mathrm{ET}_{\mathrm{c}^{\prime}}, 0 \% \mathrm{ET}_{\mathrm{c}}$ and $100 \% \mathrm{ET}_{\mathrm{c}^{\prime}}$ respectively, but no significant $(p>0.05)$ differences were recorded between SDI and MTI. However, at $40 \% \mathrm{ET}_{\mathrm{c}^{\prime}} \mathrm{SDI}$ had $15 \%$ higher yield than MTI. Biomass varied significantly $(p<0.05)$ with irrigation type and water treatment. Grain WUE varied significantly $(p<0.05)$ among the water regimes. The highest WUE was achieved under SDI at $70 \% \mathrm{ET}_{\mathrm{c}}$ but was not significantly different from that under $\mathrm{MTI}$ at $70 \% \mathrm{ET}_{\mathrm{c}}$. In conclusion, performance of cowpea was similar under the two irrigation systems under moderate DI but was better for SDI under severe DI with respect to biomass and WUE for the summer trial. Moderate DI improved the grain WUE while all the DI conditions improved the biomass WUE.

\section{INTRODUCTION}

Cowpea (Vigna unguiculata (L.) Walp) is one of the most important legumes grown in most parts of the world (Sebetha et al., 2010). It is the most commonly cultivated crop in resource-scarce countries of Africa, Asia, Central and South America, due to its ability to withstand extremely harsh environmental conditions such as high temperatures, limited water availability and poor soil fertility (Shiringani and Shimelis, 2011). It is also grown in European countries around the Mediterranean, such as Turkey (Basaran et al., 2011, Peksen, 2007). In South Africa, cowpea is cultivated in Limpopo, KwaZulu-Natal, Mpumalanga and the North West Provinces (DAFF, 2014). It can also be found in the wild in KwaZulu-Natal, Mpumalanga and Limpopo Provinces (Van Rensburg et al., 2007). Cowpea is nutritionally valuable in humans and animals. It is consumed as grains (dry and fresh) and vegetable leaves (Badiane et al., 2004) whereas the haulms are utilized as forage for livestock (Sprent et al., 2009). Cowpea grains are rich in proteins which could complement the diets of the majority of African households whose diets mainly consist of starch (Singh et al., 2003). Therefore, enhanced production of this crop would help in alleviating food insecurity in Africa.

Most of cowpea production is under rain-fed systems by small-scale farmers (Singh et al., 2003). Unavailability of rainfall or non-uniform distribution thereof means that yields cannot be guaranteed since water deficits affect plant growth and flowering (Timko and Singh, 2008). Indeed, studies have demonstrated that water deficit at flowering negatively affected yields of cowpea (Abdoul Karim et al., 2018; Ahmed and Suliman, 2010; Anyia and Herzog, 2004; Peksen, 2007). Households depending on cowpea are consequently exposed to risks of crop failure, hunger and malnutrition. Irrigation helps in stabilizing yields and acts as insurance to farmers in instances where there is rainfall variability or insufficient rainfall to meet crop requirements. Irrigation also allows for all-year round production, especially in the tropics and subtropics where temperatures are favourable for cowpea growth.

However, irrigation is the biggest consumer of freshwater resources, accounting for about $70 \%$ of total water use in arid and semi-arid areas (Fereres and Soriano, 2007). The irrigation sector in South Africa contributes about $60 \%$ of total water use (Reinders et al., 2010). This, therefore, requires adoption of efficient irrigation systems and appropriate agricultural water management practices to save water. Deficit irrigation (DI) is one of the main water-saving irrigation strategies where the

\section{CORRESPONDENCE}

Edwin Kimutai Kanda

\section{EMAIL}

Kandaedwin@gmail.com

\section{DATES}

Received: 3 May 2019

Accepted: 3 April 2020

\section{KEYWORDS}

crop growth

deficit irrigation

indigenous legume

irrigation

semi-permeable membrane water use efficiency yield

\section{COPYRIGHT}

(c) The Author(s) Published under a Creative Commons Attribution 4.0 International Licence (CC BY 4.0) 
volume of water applied is below the crop water requirement, with the aim of maximizing crop water productivity (Fereres and Soriano, 2007). Adoption of efficient irrigation methods such as subsurface drip irrigation (SDI) helps in reducing agricultural water use by minimizing non-beneficial components such as soil evaporation, runoff and drainage (Ayars et al., 1999).

Moistube irrigation (MTI) is a relatively new type of irrigation technology which originated in China. It is similar to SDI but, instead of flowing from emitters, water flows out of the Moistube membrane as a function of applied pressure and the soil water potential (Yang et al., 2008). Some studies have shown that MTI saves water and has higher water use efficiency (WUE) than conventional irrigation methods. For instance, a comparison between MTI and SDI for tomatoes showed that the former resulted in similar yield per unit area compared to the latter but also improved WUE by $13 \%$ (Xue et al., 2013). Lyu et al. (2016) found that MTI can achieve about $38 \%$ water savings compared to drip irrigation with mulch in production of tomatoes. Besides an increase in total yield, tomato quality in terms of fruit diameter, weight, Vitamin C, soluble sugar and soluble acid ratio were $8.6 \%, 12 \%, 27 \%, 4.5 \%$ and $21 \%$ higher, respectively, using MTI compared to drip irrigation. Yao et al. (2014) compared conventional irrigation, MTI, and rainfed water conditions. In the study, Moistube-irrigated navel oranges achieved the highest leaf respiration index, photosynthetic rate, specific leaf area and quantum yield. A study by Zhang et al. (2016a) established that water savings could be achieved in cabbage production using MTI, but the results could not be verified and thus further studies were recommended. Yin et al. (2017) reported 21\% water savings in MTI-irrigated spinach compared to conventional irrigation. However, Zhang et al. (2017) found that MTI decreased maize yield significantly relative to that obtained under SDI, while wheat yield only tended to decrease. In the same study, there were no significant differences in crop WUE between MTI and SDI.

Based on the above information, and the potential importance of cowpea in South Africa, it was considered necessary to evaluate the response of cowpea under the new water-saving irrigation technology (MTI) and conventional irrigation (SDI). The aim of this study, therefore, was to determine the growth, development, yield and water use efficiency of cowpea under varying water regimes under MTI and SDI. Correlation analysis was done to determine the relationships among the growth and yield variables. This study was based on two hypotheses. First, it was hypothesized that there was no significant difference between the response of cowpea under MTI and SDI, and secondly, that WUE of cowpea could be improved by a DI strategy.

\section{MATERIALS AND METHODS}

\section{Glasshouse experiment (summer season)}

This research was carried out in tunnels at the Controlled Environment Facility (CEF) of UKZN, Pietermaritzburg Campus $\left(29.58^{\circ} \mathrm{S}, 30.42^{\circ} \mathrm{E}\right)$ during summer 2018 . The experiment was carried out in a $11 \mathrm{~m}$ long glasshouse in raised beds measuring $0.75 \mathrm{~m}$ wide and $0.75 \mathrm{~m}$ high. The soil texture was loam $(42.3 \%$ sand, $33.3 \%$ silt, $24.4 \%$ clay) with a bulk density of $1.36 \mathrm{~g} \cdot \mathrm{cm}^{-3}$.

The experiment was laid out in a split-plot design arranged in randomized complete blocks. The main block was the irrigation type (SDI and MTI) while the sub-plots were 3 water regimes replicated 3 times. The water regimes imposed consisted of irrigation to meet the full crop water requirement (100\% ET), and DI of $70 \% \mathrm{ET}_{\mathrm{c}}$ and $40 \% \mathrm{ET}_{\mathrm{c}}$. The drip emitters and Moistube tapes were installed at a $15 \mathrm{~cm}$ depth, which was guided by the crop rooting depth and the need to have emitters close to the surface for crop establishment.
Cowpea (brown mix variety) was planted on 14 February 2018 (summer season). The plant spacing was $50 \mathrm{~cm}$ between rows and $30 \mathrm{~cm}$ within rows giving a plant density of 66667 plants.ha ${ }^{-1}$. A soil fertility test conducted at Cedara Agricultural College indicated that the soil required phosphorus, which was applied as Single Superphosphate (10.5\% P) at $60 \mathrm{~kg} \cdot \mathrm{ha}^{-1}$. The DI was induced from 21 days after planting (DAP).

Other agronomic management practices such as weed, pest and disease control were done according to recommended best practices developed by the then Department of Agriculture, Forestry and Fisheries of the Republic of South Africa (DAFF, 2014).

\section{Field experiment (winter season)}

Field trials were conducted at the University of KwaZulu-Natal's Ukulinga Research Farm in Pietermaritzburg (29.67 $\mathrm{S}, 30.41^{\circ}$ E) during winter 2018. These were carried out in a $12 \mathrm{~m}$ by $5 \mathrm{~m}$ tunnel where the soil texture was clay $(24.3 \%$ sand, $23.6 \%$ silt and $52.1 \%$ clay) with bulk density of $1.23 \mathrm{~g} \cdot \mathrm{cm}^{-3}$. The tunnel at Ukulinga had open ends with free movement of air to imitate field conditions as much as possible. The temperature in the tunnels varied from $4^{\circ} \mathrm{C}$ to $15^{\circ} \mathrm{C}$ during the growing period.

The experimental layout, cowpea variety, plant spacing, Moistube and SDI placement depth were similar to that described for the glasshouse experiment. The crop was planted on 25 May 2018 (winter season). Soil fertility test indicated that the soil did not have a nutrient deficiency and, therefore, fertilizers were not added. The DI water regimes were introduced 30 DAP when the crops were fully established. The long crop establishment period was due to the low temperatures which affected emergence. Other agronomic management practices were done according to recommended best practices as described in the glasshouse experiment.

\section{Estimation of crop water requirements}

The crop water requirements $\left(\mathrm{ET}_{\mathrm{c}}\right)$ for each crop growth stage were determined using potential reference evapotranspiration and crop coefficients as described in Allen et al. (1998). The crop coefficients adopted for cowpea were $0.4,1.1$ and 0.4 for the initial, mid- and end-growth stage, respectively.

The net irrigation requirement $\left(I_{\text {net }}\right)$ was calculated as $\mathrm{ET}_{\mathrm{c}}$ less rainfall. Since rainfall equalled zero, the $I_{\text {net }}$ was equal to $\mathrm{ET}_{\mathrm{c}}$. The water use efficiency was determined as the ratio of the yield to the amount of irrigation applied.

The different water regimes were applied by varying the irrigation interval in such a way that the total amount of irrigation was $100 \%, 70 \%$ and $40 \%$ of $\mathrm{ET}_{\mathrm{c}}$. In SDI, the amount of water applied per irrigation event was the same, but the irrigation interval was different for the DI, i.e., $100 \% \mathrm{ET}_{c}<70 \% \mathrm{ET}_{c}<40 \% \mathrm{ET}_{c}$. A drip emitter of nominal flow rate of $1.6 \mathrm{~L} \cdot \mathrm{h}^{-1}$ was used in this study. This flowrate was used to calculate the amount of water to be applied at every irrigation event. The flow from Moistube was in the range of $0.24 \mathrm{~L} \cdot \mathrm{h}^{-1} \cdot \mathrm{m}^{-1}$ at $20 \mathrm{kPa}$ to $1.73 \mathrm{~L} \cdot \mathrm{h}^{-1} \cdot \mathrm{m}^{-1}$ at $100 \mathrm{kPa}$ (Kanda et al., 2018). The pressure was adjusted according to the crop water requirement. MTI was supposed to be continuous, i.e., water applied throughout the cropping cycle but the pressure regulators available were not sufficiently low to allow for continuous water application. Therefore, the water application was applied intermittently ranging from 3 days continuously per dekad, 5 days and 8 days per dekad for $40 \% \mathrm{ET}_{\mathrm{c}}, 70 \% \mathrm{ET}_{\mathrm{c}}$ and $100 \% \mathrm{ET}_{\mathfrak{c}}$, respectively. 


\section{Data collection and analysis}

Weather data were obtained inside the tunnel using HOBO data logger sensors (Onset Computer Corporation, USA). The variables measured were temperature, relative humidity and solar radiation, while wind speed was measured using a Kestrel 3000 anemometer (Nielsen-Kellerman, Inc. USA) which were mounted $2 \mathrm{~m}$ above the ground.

Leaf area index (LAI) was measured weekly using the LAI2200 canopy analyser (LI-COR Inc. USA). The time to $50 \%$ flowering was determined by counting the number of flowered plants and was taken as days elapsed until $50 \%$ of the plants in each plot had flowered. Determination of yield components was done by sampling 10 plants per plot excluding border plants. All the pods from each plant were harvested, counted and then shelled for yield analysis. Aboveground biomass of each of the 10 plants per plot was determined by cutting each plant and then weighing after air drying for 3 weeks. For the field experiment, 5 plants in the inner row, excluding border plants, were harvested and weighed after air drying to determine the biomass.

The harvest index (HI) was computed using Eq. 1 (Cisse, 2001):

$$
\mathrm{HI}=\frac{\text { Grain yield }\left(\mathrm{kg} \mathrm{ha}^{-1}\right)}{\text { Biomass }\left(\mathrm{kg} \mathrm{ha}^{-1}\right)} \times 100 \%
$$

The water use efficiency (WUE) was computed using Eq. 2 (Albaji et al., 2011):

$$
\text { WUE }=\frac{\text { Yield or Biomass }\left(\mathrm{kg} \mathrm{ha}^{-1}\right)}{\text { Amount of irrigation applied }\left(\mathrm{m}^{3} \mathrm{ha}^{-1}\right)}
$$

The amount of irrigation applied was the cumulative irrigation depth $(\mathrm{mm})$ applied during the irrigation events and then converted to volume per hectare.

The measured data was analysed using GenStat version 18 (VSN International, Hemel Hempstead, UK) to determine ANOVA of the variables. Separation of means of significant variables was done using Duncan's Least Significant Differences (LSD) at a $5 \%$ significance level in GenStat. Correlation analyses were carried out on growth and yield components to determine the relationship between variables.

\section{RESULTS AND DISCUSSION}

\section{Leaf area index}

LAI is an important growth parameter as it signifies the extent of the assimilative capacity of a crop under existing

Table 1. Effect of irrigation type and deficit irrigation on LAl for the summer experiment

\begin{tabular}{lcc}
\hline Irrigation & Water regime & Mean seasonal LAI \\
\hline Moistube & $100 \% \mathrm{ET}_{\mathrm{c}}$ & $2.59^{\mathrm{a}}$ \\
$\mathrm{SDI}$ & $100 \% \mathrm{ET}_{\mathrm{c}}$ & $2.55^{\mathrm{a}}$ \\
Moistube & $70 \% \mathrm{ET}_{\mathrm{c}}$ & $2.39^{\mathrm{ab}}$ \\
$\mathrm{SDI}$ & $70 \% \mathrm{ET}_{\mathrm{c}}$ & $2.40^{\mathrm{ab}}$ \\
Moistube & $40 \% \mathrm{ET}_{\mathrm{c}}$ & $1.93^{\mathrm{b}}$ \\
$\mathrm{SDI}$ & $40 \% \mathrm{ET}_{\mathrm{c}}$ & $2.21^{\mathrm{ab}}$ \\
$\mathrm{LSD}$ (irrigation) & & 0.3062 \\
$\mathrm{LSD}$ (ET) & & 0.3751 \\
$\mathrm{LSD}_{c}$ (irrigation $\times \mathrm{ET}_{c}$ ) & & 0.5304 \\
\hline
\end{tabular}

Mean values in same column followed by same superscript letter do not significantly differ at 5\% level of significance by LSD. Data in parentheses are the standard deviations environmental conditions (Farooq et al., 2012). The LAI varied among the treatments in both experiments. In the summer trials, there were no significant differences between the two types of irrigation (Table 1), but LAI under SDI at $40 \% \mathrm{ET}_{c}$ was significantly $(p<0.05)$ higher than MTI at $40 \% \mathrm{ET}_{c}$ (Fig. 1). There was no significant difference between SDI and MTI at full irrigation $\left(100 \% \mathrm{ET}_{c}\right)$ and moderate $\left(70 \% \mathrm{ET}_{c}\right)$ deficit irrigation $(p>0.05)$. The LAI was significantly lower under MTI at $40 \%$ $\mathrm{ET}_{c}$ compared to both SDI and MTI at $100 \% \mathrm{ET}_{c}$ water regimes (Table 1).

The LAI for the winter trials showed variations among treatments and irrigation type (Table 2). The mean seasonal LAI was not significantly $(p>0.05)$ different between MTI and SDI at $100 \% \mathrm{ET}_{\mathrm{c}}$. However, LAI under MTI was significantly lower than SDI at $70 \% \mathrm{ET}$. At $40 \% \mathrm{ET}$ the LAI became significantly lower compared to the wetter regimes after 10 weeks (Fig. 2). The LAI of $100 \% \mathrm{ET}_{\mathrm{c}}$ MTI plants was significantly $(p<0.05)$ lower than where $100 \%$ and $70 \% \mathrm{ET}_{\mathrm{c}}$ SDI was applied after 10 weeks (Fig. 2).

Full irrigation in the summer season experiments resulted in a seasonal peak LAI of 4 and 3.88 for MTI and SDI, respectively (Fig. 1). Applying MTI at 40\% ET resulted in the lowest seasonal peak LAI. The seasonal mean LAI of MTI plants irrigated at $40 \%$ $\mathrm{ET}_{c}$ decreased significantly (25.6\%) compared to those receiving $100 \% \mathrm{ET}_{c}$ MTI and SDI $(p<0.05)$ (Table 1). These results were consistent with those reported by Souza et al. (2017) where LAI declined by between $13 \%$ and $47 \%$ due to water deficit. The reduction in LAI could be attributed to decreased leaf appearance rate and abscission which are considered as drought avoidance mechanisms (Abayomi and Abidoye, 2009). Reduction in leaf area due to water deficit arises because of inhibited cell growth (Fathi and Tari, 2016). According to Prasad et al. (2008), mild water deficit causes reduction in leaf number, retarded leaf expansion rate and reduced leaf size while severe water deficit inhibits leaf appearance.

Significant $(p<0.05)$ seasonal differences in cowpea growth between the summer and winter trials were reflected by the seasonal LAI trends. During winter, most of the growth parameters were affected by the night temperatures, which were in most cases very low $\left(<10^{\circ} \mathrm{C}\right)$. The low temperatures significantly delayed time to emergence $(\approx 15$ days $)$ and led to slower leaf area development (LAI $\leq 1)$ compared to summer trials where cowpea emerged after an average of 7 days and reached a higher LAI $(\geq 1.9)$. As illustrated in Figs 1 and 2, the maximum LAI was significantly lower $(p<0.05)$ for the winter compared to the summer experiment. Ntombela (2012) found that low temperature limited growth characteristics

Table 2. Effect of irrigation type and deficit irrigation on LAI for the winter experiment

\begin{tabular}{lll}
\hline Irrigation & Water regime & Mean seasonal LAI \\
\hline Moistube & $100 \% \mathrm{ET}_{\mathrm{c}}$ & $0.41^{\mathrm{abc}}$ \\
$\mathrm{SDI}$ & $100 \% \mathrm{ET}_{\mathrm{c}}$ & $0.55^{\mathrm{a}}$ \\
Moistube & $70 \% \mathrm{ET}_{\mathrm{c}}$ & $0.36^{\mathrm{c}}$ \\
$\mathrm{SDI}$ & $70 \% \mathrm{ET}_{\mathrm{c}}$ & $0.51^{\mathrm{ab}}$ \\
Moistube & $40 \% \mathrm{ET}_{\mathrm{c}}$ & $0.31^{\mathrm{c}}$ \\
$\mathrm{SDI}$ & $40 \% \mathrm{ET}_{\mathrm{c}}$ & $0.37^{\mathrm{bc}}$ \\
$\mathrm{LSD}$ (irrigation) & & 0.0795 \\
$\mathrm{LSD}$ (ET) & & 0.0973 \\
$\mathrm{LSD}$ (irrigation $\left.\times \mathrm{ET}_{c}\right)$ & & 0.1377 \\
\hline
\end{tabular}

Mean values in same column followed by same superscript letter do not significantly differ at 5\% level of significance by LSD. Data in parentheses are the standard deviations 
of cowpea more than water deficit. Therefore, irrespective of water availability, temperature is a significant factor in cowpea growth. This may be the reason for its popularity in tropical and subtropical countries in Sub-Saharan Africa, Asia, central and South America (Singh et al., 2003).

\section{Time to flowering}

Water deficit affects crop growth and development by not only retarding cell division and expansion but also by altering the initiation and duration of phenological stages (Prasad et al., 2008). Time to flowering is an environmental adaptive feature of most annual crops (Ishiyaku et al., 2005). In the present study, the cowpea grown in winter failed to flower due to low temperatures, which was consistent with results reported by Ilunga (2014) where cowpea planted in June (winter season), at the same site, failed to flower.

In the summer experiment, the number of days to $50 \%$ flowering varied significantly $(p<0.05)$ across the water regimes, as shown in Table 3. Cowpea flowered earlier at $40 \% \mathrm{ET}_{\mathrm{c}}$ for both MTI and SDI compared to $70 \% \mathrm{ET}_{\mathrm{c}}$ for SDI and the fully irrigated treatments. Full irrigation under MTI significantly delayed time to $50 \%$ flowering (10 days) compared to plants subjected to severe deficit (40\% ET) and MTI 70\% ET. The latter treatment flowered 4 days later than MTI $40 \% \mathrm{ET}_{\mathfrak{c}}$, but they were not significantly

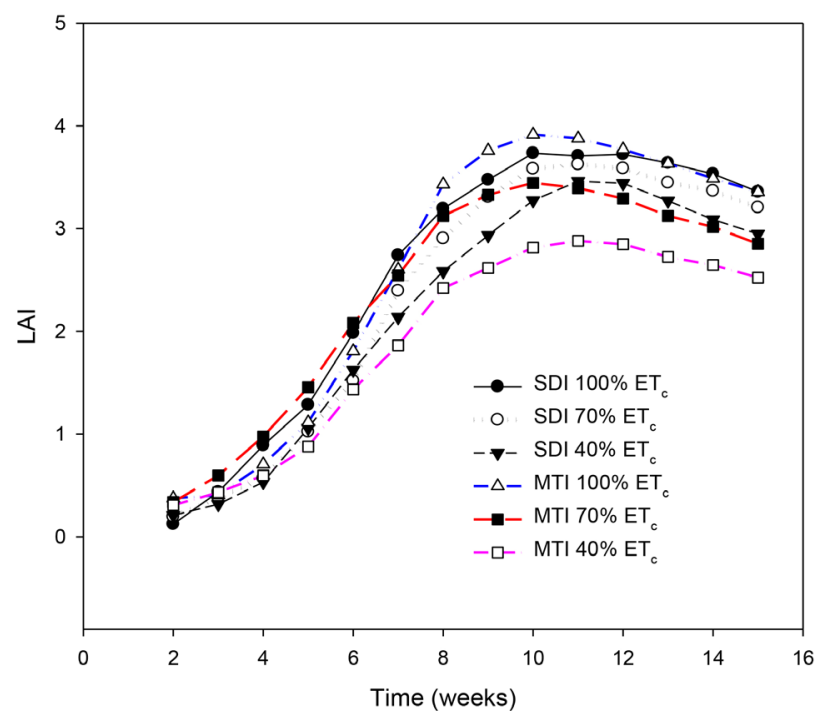

Figure 1. Leaf area index for different irrigation treatments of the summer experiment

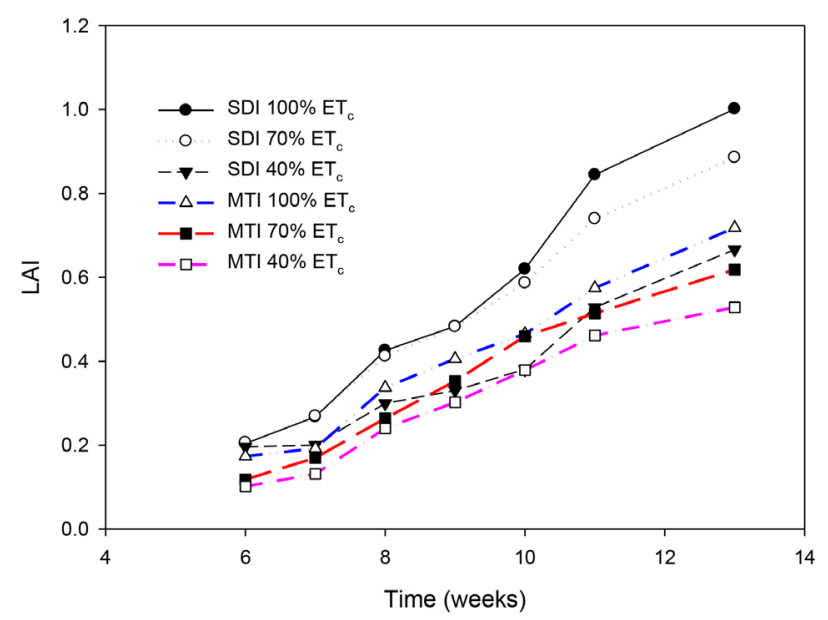

Figure 2. Leaf area index for different irrigation treatments of the winter experiment different $(p>0.05)$. Cowpea receiving SDI at $100 \% \mathrm{ET}_{\mathrm{c}}$ took significantly longer to reach the $50 \%$ flowering stage than plants subjected to all the other water regimes.

The accelerated time to flowering due to water deficit reported in this study was consistent with that reported by Ilunga (2014) for the same variety (mixed brown), where rain-fed induced water deficit enhanced time to flowering by 7 days. The MTI supplies water to the crop at $80-90 \%$ of field capacity (Zhang et al., 2012) and hence a subsequent decrease in water, e.g $70 \% \mathrm{ET}_{c}$, results in slightly lower water availability to the crop than at $70 \% \mathrm{ET}_{c}$ under SDI. This could possibly explain the non-significant difference between time to $50 \%$ flowering under $70 \% \mathrm{ET}_{c}$ SDI and $100 \% \mathrm{ET}_{c}$ under MTI. The shorter duration to flowering as a result of water deficit is considered to be a drought escape mechanism in cowpea (Ehlers and Hall, 1997). However, some studies have reported delayed flowering due to water stress (Abayomi and Abidoye, 2009, Faloye and Alatise, 2017, Ntombela, 2012). The response of time to flowering under water deficit in cowpea depends on the genotype, as found by Dadson et al. (2005) where some exhibited early flowering while others had delayed flowering.

\section{Yield and yield components}

The cowpea at the field trial failed to flower due to low temperatures during the winter season and, therefore, the results reported here for the yield components and biomass were for the summer experiment, while only biomass was reported for the winter season.

Irrigation system type and deficit irrigation levels affected yield and yield components of the summer trial significantly (Table 4). Irrigation system type did not affect pod number or mass significantly, nor seed mass per plant. It also had no significant effect on grain yield or shelling percentage. SDI compared to MTI tended to increase biomass per plant and per hectare, but these were only significantly higher at the $70 \%$ and $40 \% \mathrm{ET}_{c}$ deficit irrigation levels.

Deficit irrigation at $70 \%$ and $40 \% \mathrm{ET}_{\mathrm{c}}$ decreased pods, pod mass, seed mass and biomass per plant as well as grain yield significantly, compared to where irrigation was applied at $100 \%$ $\mathrm{ET}_{c}$, irrespective of irrigation system type. Compared to SDI at $100 \% \mathrm{ET}_{c}$, a significant reduction in yield (57.7\%) was recorded at $40 \% \mathrm{ET}_{\mathrm{c}}$ under MTI while drip at $40 \% \mathrm{ET}_{\mathrm{c}}$ led to a decline in yield by $50.2 \%$. Similarly, the decline in yield at $70 \% \mathrm{ET}_{\mathrm{c}}$ relative

Table 3. Effect of irrigation system and deficit irrigation on cowpea time to flowering

\begin{tabular}{lcc}
\hline Irrigation type & Water regime & $\begin{array}{c}\text { Time to flowering } \\
\text { (days) }\end{array}$ \\
\hline Moistube & $100 \% \mathrm{ET}_{c}$ & $65.7(3.06)^{\mathrm{b}}$ \\
$\mathrm{SDI}$ & $100 \% \mathrm{ET}_{\mathrm{c}}$ & $74.3(4.16)^{\mathrm{c}}$ \\
Moistube & $70 \% \mathrm{ET}_{\mathrm{c}}$ & $59.7(4.51)^{\mathrm{a}}$ \\
$\mathrm{SDI}$ & $70 \% \mathrm{ET}_{\mathrm{c}}$ & $67.3(2.08)^{\mathrm{b}}$ \\
Moistube & $40 \% \mathrm{ET}_{\mathrm{c}}$ & $55.3(2.52)^{\mathrm{a}}$ \\
$\mathrm{SDI}$ & $40 \% \mathrm{ET}_{\mathrm{c}}$ & $56.7(2.08)^{\mathrm{a}}$ \\
$\mathrm{LSD}$ (Irrigation) & & 3.3 \\
$\mathrm{LSD}$ (ET) & & 4.04 \\
$\mathrm{LSD}$ (Irrigation $\times \mathrm{ET}_{c}$ ) & & 5.72 \\
$\mathrm{CV}$ (\%) & & 5.1 \\
\hline
\end{tabular}

Mean values in the same column followed by the same superscript letter do not significantly differ at $5 \%$ level of significance by $L S D$. Data in parentheses are the standard deviations 
to the fully irrigated crop was $20.5 \%$ and $13.9 \%$ under MTI and SDI, respectively.

The results were similar to those found by Mousa and Qurashi (2017), where water deficit reduced the number of pods per plant. Abayomi and Abidoye (2009) also found reduced pod weight and number of seeds per plant due to water deficit. In another study, Hamidou et al. (2007) reported an average reduction of $60 \%$ in the number of pods per plant due to water deficit. The reduction in the number of pods per plant could be attributed to a lower number of flower buds and loss of flowers due to water deficit in the reproductive stage (Abdoul Karim et al., 2018; Maleki et al., 2017)

Deficit irrigation reduced yields, mainly due to significantly lower LAI, pod number per plant, pod mass per plant and harvest index. Maleki et al. (2017) reported a decline of between $4 \%$ and $59 \%$ in cowpea yields under a water regime of $40-80 \%$ of full irrigation. Reduction in yield due to water deficit is attributed to reduced photosynthetic active radiation absorption rate by plants and reduction in radiation efficiency (Fathi and Tari, 2016). According to Prasad et al. (2008), water deficit generally reduces grain yields, since it affects biomass production prior to flowering and negatively affects the reproduction phase of pollination as well as biomass partitioning during yield formation. Water deficit leads to a decline in leaf expansion, lower production of leaves and leaf senescence, which ultimately decreases the biomass (Figueiredo et al., 2001). Besides reduced leaf area, Anyia and Herzog (2004) associated decline in biomass of cowpea with reduced leaf gas exchange due to water deficit.
The significantly low temperatures during winter reduced the biomass compared to the summer season (Tables 4 and 5). There was no significant difference in biomass between the two irrigation system types. However, there were significant differences among the three water regimes where $40 \%$ ET resulted in significantly lower biomass compared to $70 \% \mathrm{ET}_{c}$ and $100 \% \mathrm{ET}$. However, biomass at $70 \% \mathrm{ET}$ and $100 \% \mathrm{ET}$ c were not significantly different. Biomass was significantly correlated to LAI $(r=0.76, p<0.05)$, as in Table 6. The low biomass produced during the winter season (Table 5) may therefore be attributed to low LAI (Fig. 2). The low LAI was contributed by cold stress which inhibited leaf expansion. The findings concurred with those found by Ntombela (2012) where cold temperatures significantly reduced cowpea yield compared to water deficit.

Yield is a product of several components such as number of germinated plants, dry matter partitioning, numbers of seeds, and size of the seeds (Prasad et al., 2008). There was a strong positive correlation between the total grain yield and number of pods per plant $(r=0.97)$, pod mass per plant $(r=0.96)$, number of seeds per plant $(r=0.96)$, biomass and harvest index $(r=0.94)$ as shown in Table 6. Among these attributes, pod mass and harvest index had a significant contribution to grain yield ( $p<$ $0.05)$. Total grain yield $(r=0.85)$ and biomass $(r=0.76)$ were significantly correlated with LAI $(p<0.05)$. However, yield was strongly and negatively correlated with the number of days to $50 \%$ flowering $(r=-0.80)$.

Table 4. Effect of irrigation system type and deficit irrigation on yield and yield components for the summer trial

\begin{tabular}{|c|c|c|c|c|c|c|c|c|c|c|}
\hline Irrigation & $\begin{array}{c}\text { Water } \\
\text { regime }\end{array}$ & $\begin{array}{l}\text { Pods/ } \\
\text { plant }\end{array}$ & $\begin{array}{c}\text { Pod mass/ } \\
\text { plant (g) }\end{array}$ & $\begin{array}{l}\text { Seeds/ } \\
\text { plant }\end{array}$ & $\begin{array}{c}\text { Seed mass/ } \\
\text { plant }^{-}(g)\end{array}$ & $\begin{array}{l}\text { Biomass/ } \\
\text { plant (g) }\end{array}$ & $\begin{array}{l}\text { Grain yield } \\
\left(\mathbf{k g} \cdot \mathrm{ha}^{-1}\right)\end{array}$ & $\begin{array}{l}\text { Biomass } \\
\left(\mathbf{k g} \cdot \mathbf{h a}^{-1}\right)\end{array}$ & $\begin{array}{c}\text { Harvest } \\
\text { Index (\%) }\end{array}$ & $\begin{array}{c}\text { Shelling } \\
(\%)\end{array}$ \\
\hline Moistube & $100 \%$ ETc & $24(7)^{c}$ & $67.8(16.7)^{c}$ & $350(94)^{c}$ & $48.3(9.6)^{c}$ & $139.1(18.7)^{\mathrm{e}}$ & $3189(634)^{c}$ & $9272(1247)^{\mathrm{e}}$ & $34.8(5.3)^{c}$ & $72.4(8.0)^{\mathrm{ab}}$ \\
\hline SDI & $100 \%$ ETc & $25(7)^{c}$ & $67.3(20.7)^{c}$ & $345(101)^{c}$ & $45.8(10.5)^{c}$ & $145.2(16.5)^{\mathrm{e}}$ & $3025(695)^{c}$ & $9678(1098)^{\mathrm{e}}$ & $31.5(6.2)^{b}$ & $70.5(11.7)^{a b}$ \\
\hline Moistube & $70 \% \mathrm{ETC}$ & $19(6)^{b}$ & $50.1(17.6)^{b}$ & $268(95)^{b}$ & $36.4(9.4)^{b}$ & $120.2(15.7)^{\mathrm{c}}$ & $2401(612)^{b}$ & $8012(1048)^{c}$ & $30.1(5.5)^{b}$ & $75.1(13.0)^{\mathrm{b}}$ \\
\hline SDI & $70 \%$ ETc & $19(6)^{b}$ & $52.1(15.8)^{b}$ & $315(96)^{c}$ & $39.5(10.6)^{b}$ & $128.9(20.1)^{d}$ & $2605(701)^{b}$ & $8590(1339)^{d}$ & $30.5(6.0)^{b}$ & $77.3(11.8)^{b}$ \\
\hline Moistube & $40 \% \mathrm{ETc}$ & $11(5)^{a}$ & $29.9(19.4)^{a}$ & $162(84)^{a}$ & $19.4(9.1)^{a}$ & $85.5(10.0)^{a}$ & $1280(598)^{a}$ & $5701(926)^{a}$ & $22.4(9.2)^{\mathrm{a}}$ & $71.23(20.6)^{\mathrm{ab}}$ \\
\hline SDI & $40 \%$ ETc & $13(5)^{a}$ & $36.7(15.3)^{\mathrm{a}}$ & $175(60)^{\mathrm{a}}$ & $22.8(7.0)^{\mathrm{a}}$ & $100.4(18.9)^{b}$ & $1505(462)^{a}$ & $6694(1263)^{b}$ & $22.6(4.8)^{\mathrm{a}}$ & $66.54(17.8)^{\mathrm{a}}$ \\
\hline LSD (Irrigation) & & 1.8 & 5.2 & 9.5 & 2.6 & 5.3 & 88.3 & 350.6 & 1.72 & 2.6 \\
\hline $\operatorname{LSD}\left(\mathrm{ET}_{c}\right)$ & & 2.3 & 6.4 & 11.6 & 3.2 & 6.44 & 108.1 & 429.4 & 2.1 & 3.1 \\
\hline LSD (Irr x ET $)$ & & 3.2 & 9.0 & 16.4 & 4.6 & 9.11 & 152.9 & 607.2 & 2.9 & 4.4 \\
\hline CV (\%) & & 24.1 & 24.5 & 23.3 & 20.9 & 15.3 & 20.9 & 15.3 & 17.4 & 13.3 \\
\hline
\end{tabular}

Mean values in the same column followed by the same superscript letter do not significantly differ at $5 \%$ level of significance by $L S D$. Data in parentheses are the standard deviations

Table 5. Effect of irrigation system type and deficit irrigation on biomass for the winter trial

\begin{tabular}{|c|c|c|c|}
\hline Irrigation & Water regime & Biomass/plant (g) & Total biomass $\left(\mathbf{k g} \cdot \mathbf{h a}^{-1}\right)$ \\
\hline Moistube & $100 \% \mathrm{ET}_{c}$ & $27.36(8.97)^{b}$ & $1824(598.12)^{b}$ \\
\hline SDI & $100 \% \mathrm{ET}_{\mathrm{c}}$ & $31.11(9.15)^{b}$ & $2074(610.03)^{b}$ \\
\hline Moistube & $70 \% \mathrm{ET}_{\mathrm{c}}$ & $26.10(7.39)^{b}$ & $1740(492.38)^{b}$ \\
\hline SDI & $70 \% \mathrm{ET}_{\mathrm{c}}$ & $28.53(8.99)^{b}$ & $1902(599.99)^{b}$ \\
\hline Moistube & $40 \% \mathrm{ET}_{\mathrm{c}}$ & $17.38(7.82)^{a}$ & $1159(521.34)^{a}$ \\
\hline SDI & $40 \% \mathrm{ET}_{c}$ & $10.94(4.88)^{a}$ & $729(325.3)^{a}$ \\
\hline LSD (Irrigation) & & 3.943 & 262.9 \\
\hline $\operatorname{LSD}\left(\mathrm{ET}_{\mathrm{c}}\right)$ & & 4.829 & 322.0 \\
\hline LSD (Irrigation x ET ${ }_{c}$ ) & & 6.830 & 455.3 \\
\hline CV (\%) & & 24.3 & 24.3 \\
\hline
\end{tabular}

Mean values in the same column followed by the same superscript letter do not significantly differ at 5\% level of significance by LSD. Data in parentheses are the standard deviations 
Table 6. Correlation analysis of growth and yield components for CEF experiment

\begin{tabular}{|c|c|c|c|c|c|c|c|c|}
\hline & Pod No. & $\begin{array}{l}\text { Pod mass/ } \\
\text { Plant }\end{array}$ & $\begin{array}{l}\text { Seeds/ } \\
\text { plant }\end{array}$ & $\begin{array}{c}\text { Grain yield } \\
\left(\mathbf{k g} \cdot \mathbf{h a}^{-1}\right)\end{array}$ & $\begin{array}{l}\text { Biomass } \\
\left(\mathbf{k g} \cdot \mathbf{h a}^{-1}\right)\end{array}$ & $\begin{array}{c}\text { Harvest index } \\
(\%)\end{array}$ & LAI & Days to flowering \\
\hline Pods & 1.00 & & & & & & & \\
\hline Pod mass/plant & 0.99 & 1.00 & & & & & & \\
\hline Seeds/plant & 0.96 & 0.97 & 1.00 & & & & & \\
\hline Grain yield $\left(\mathrm{kg} \cdot \mathrm{ha}^{-1}\right)$ & 0.97 & 0.96 & 0.96 & 1.00 & & & & \\
\hline Biomass $\left(\mathrm{kg} \cdot \mathrm{ha}^{-1}\right)$ & 0.98 & 0.98 & 0.98 & 0.98 & 1.00 & & & \\
\hline Harvest index (\%) & 0.95 & 0.94 & 0.95 & 0.94 & 0.93 & 1.00 & & \\
\hline LAI & 0.85 & 0.85 & 0.78 & 0.85 & 0.76 & 0.89 & 1.00 & \\
\hline Days to flowering & -0.83 & -0.81 & -0.77 & -0.80 & -0.71 & -0.78 & -0.77 & 1.00 \\
\hline
\end{tabular}

\section{Water use efficiency}

Grain WUE varied significantly among the water regimes for the summer crop (Table 7). The highest grain WUE was achieved under SDI at $70 \% \mathrm{ET}$, but it was comparable to that of plants receiving MTI at $70 \% \mathrm{ET}$. MTI at $40 \%$ had the lowest grain WUE. Irrigation type did not significantly affect grain WUE at $100 \%$ ET. With respect to SDI, DI of $70 \% \mathrm{ET}_{c}$ and $40 \%$ $\mathrm{ET}_{c}$ improved grain WUE relative to the fully irrigated crop by $17.3 \%$ and $4.9 \%$, respectively. In MTI, DI improved grain WUE by $4.1 \%$ at $70 \% \mathrm{ET}_{\mathrm{c}}$, but it decreased by $17 \%$ at $40 \% \mathrm{ET}_{\mathrm{c}}$. This shows that DI at $40 \%$ under MTI is not beneficial for grain yield in relation to water consumption.

Biomass WUE showed significant variations across the three water regimes $(p<0.05)$. However, the type of irrigation did not significantly $(p>0.05)$ affect the biomass WUE in all the water regimes except at SDI at $40 \% \mathrm{ET}_{c}$ where it was the highest. The DI significantly improved WUE by up to $45.8 \%$ and $21.2 \%$ for the $40 \% \mathrm{ET}_{\mathrm{c}}$ and $70 \% \mathrm{ET}_{\mathrm{c}}$ regimes, respectively. Therefore, in areas of water scarcity, cowpea can rather be grown for biomass than for grain yield. The cowpea variety used in this study (mixed brown) favours vegetative growth, thus gives more biomass than grain yield (Ilunga, 2014). The results of this study were consistent with those of Maleki et al. (2017), where the grain WUE was

Table 7. Water use efficiency for cowpea under MTI and SDI for summer experiment

\begin{tabular}{|c|c|c|c|}
\hline \multirow{2}{*}{ Water regime } & \multirow{2}{*}{$\begin{array}{l}\text { Amount } \\
\text { of water } \\
\text { applied } \\
\left(\mathrm{m}^{3} \cdot \mathrm{ha}^{-1}\right)\end{array}$} & \multicolumn{2}{|c|}{$\begin{array}{c}\text { Water use efficiency } \\
\left(\mathbf{k g} \cdot \mathrm{m}^{-3}\right)\end{array}$} \\
\hline & & Grain (SD) & Biomass (SD) \\
\hline $\begin{array}{l}\text { Moistube } 100 \% \\
\mathrm{ET}_{c}\end{array}$ & 3480 & $0.916(0.182)^{a b}$ & $2.664(0.358)^{a}$ \\
\hline SDI $100 \% \mathrm{ET}_{\mathrm{c}}$ & 3690 & $0.820(0.188)^{a b}$ & $2.623(0.298)^{a}$ \\
\hline Moistube $70 \% \mathrm{ET}_{\mathrm{c}}$ & 2520 & $0.954(0.243)^{b}$ & $3.179(0.416)^{b}$ \\
\hline SDI $70 \% \mathrm{ET}_{\mathrm{c}}$ & 2710 & $0.961(0.259)^{b}$ & $3.170(0.494)^{b}$ \\
\hline Moistube $40 \% \mathrm{ET}_{\mathrm{c}}$ & 1750 & $0.790(0.369)^{\mathrm{a}}$ & $3.519(0.411)^{c}$ \\
\hline $\mathrm{SDI} 40 \% \mathrm{ET}_{\mathrm{c}}$ & 1620 & $\begin{array}{c}0.860(0.264) \\
\text { ab }\end{array}$ & $3.825(0.722)^{d}$ \\
\hline $\left.\mathrm{LSDET}_{c}\right)$ & & 0.093 & 0.169 \\
\hline LSD (Irrigation) & & 0.076 & 0.138 \\
\hline $\begin{array}{l}\text { LSD (Irrigation } \\
x_{\mathrm{ET}} \text { ) }\end{array}$ & & 0.132 & 0.239 \\
\hline CV (\%) & & 19.2 & 14.8 \\
\hline
\end{tabular}

Mean values in same column followed by same superscript letter do not significantly differ at 5\% significance level by LSD. Data in parentheses are the standard deviations. highest at $80 \%$ of full irrigation compared to $60 \%$ and $40 \%$. Similarly, Mousa and Qurashi (2017) reported increased WUE under water deficit imposed at various growth stages, except during a combination of the flowering and pod filling stages, where it decreased marginally. However, Ahmed and Suliman (2010) reported decreased WUE due to water deficit which was attributed to reduced photosynthetic activity.

The results reported in this study were consistent with those reported in other studies on MTI. For instance, Zhang et al. (2017) found significantly lower summer maize yields in MTI compared to SDI. In the same study, the yield of winter wheat was higher under SDI than MTI, but was not significantly different. Further, WUE was not significantly different between SDI and MTI in both maize and wheat. In another study, Zhang et al. (2016b), found that SDI marginally increased WUE of summer maize compared to MTI due to the former having a $2 \%$ higher average soil moisture content over the growing season. Therefore, the crop performance under MTI and SDI is not significantly different.

\section{CONCLUSION}

The results of this study showed that growth parameters of cowpea, i.e., LAI and phenology (time to 50\% flowering) showed significant variations under MTI and SDI. For both irrigation system types, water deficit reduced the LAI and hastened the time to $50 \%$ flowering. The time to flowering was generally shorter under MTI than SDI. During the summer trial, grain yield was not affected significantly by irrigation type. However, there was significant variation in biomass between MTI and SDI with the former recording lower values than the latter. Biomass during the winter trial was not significantly different between MTI and SDI. Water deficit significantly reduced the yield and biomass of cowpea during the summer trial, especially at $40 \%$ ET . During the winter trial, water deficit had a significant effect only at $40 \% \mathrm{ET}_{c}$. Therefore, the hypothesis that the response of cowpea under both SDI and MTI is the same is rejected.

The grain WUE was improved by water deficit under SDI but only at $70 \% \mathrm{ET}_{\mathrm{c}}$ under MTI. Biomass WUE was significantly improved by increasing water deficit under both SDI and MTI, but this occurred to a greater extent under SDI. Therefore, the hypothesis that DI improves WUE of cowpea was accepted for biomass. The mixed brown variety of cowpea used in this study is highly vegetative and thus more suitable for biomass production rather than grain yield. Therefore, it is best suited as a leafy vegetable and fodder for human and animal consumption, respectively. This implies that DI could be a successful agricultural water management strategy in waterscarce regions. 


\section{ACKNOWLEDGEMENTS}

The authors are grateful to the Association of African Universities (AAU), University of KwaZulu-Natal, Masinde Muliro University of Science and Technology and National Research Fund (NRF) of Kenya for funding this study.

\section{REFERENCES}

ABAYOMI YA and ABIDOYE TO (2009) Evaluation of cowpea genotypes for soil moisture stress tolerance under screen house conditions. Afr. J. Plant Sci. 3 (10) 229-237.

ABDOUL KARIM TD, SANOUSSI A, MAÂROUHI IM, FALALOU H and YACOUBOU B (2018) Effect of water deficit at different stages of development on the yield components of cowpea (Vigna unguiculata L. Walp) genotype. Afr. J. Biotechnol. 17 (9) 279-287. https://doi. org/10.5897/AJB2017.16347

AHMED FE and SULIMAN ASH (2010) Effect of water stress applied at different stages of growth on seed yield and water-use efficiency of cowpea. Agric. Biol. J. N. Am. 1 (4) 534-540.

ALBAJI M, NASAB SB, BEHZAD M, NASERI A, SHAHNAZARI A, MESKARBASHEE M, JUDY F, JOVZI M and SHOKOOHFAR AR (2011) Water productivity and water use efficiency of sunflower under conventional and limited irrigation. J. Food, Agric. Environ. 9 (1) 202-209.

ALLEN RG, PEREIRA LS, RAES D and SMITH M (1998) Crop evapotranspiration - Guidelines for computing crop water requirements. FAO Irrigation and Drainage Paper 56. FAO, Rome, Italy.

ANYIA AO and HERZOG H (2004) Water-use efficiency, leaf area and leaf gas exchange of cowpeas under mid-season drought. Eur. J. Agron. 20 (4) 327-339. https://doi.org/10.1016/S1161-0301(03)00038-8

AYARS JE, PHENE CJ, HUTMACHER RB, DAVIS KR, SCHONEMAN RA, VAIL SS and MEAD RM (1999) Subsurface drip irrigation of row crops: a review of 15 years of research at the Water Management Research Laboratory. Agric. Water Manage. 42 1-27. https://doi. org/10.1016/S0378-3774(99)00025-6

BADIANE FA, DIOUF D, SANÉ D, DIOUF O, GOUDIABY V and DIALLO N (2004) Screening cowpea [Vigna unguiculata (L.) Walp.] varieties by inducing water deficit and RAPD analyses. Afr. J. Biotechnol. 3 (3) 174-178. https://doi.org/10.5897/AJB2004.000-2030

BASARAN U, AYAN I, ACAR Z, MUT H and ASCI OO (2011) Seed yield and agronomic parameters of cowpea (Vigna unguiculata L.) genotypes grown in the Black Sea region of Turkey. Afr. J. Biotechnol. 10 (62) 13461-13464. https://doi.org/10.5897/AJB11.2489

CISSE N (2001) Genotype x row spacing and environment interaction of cowpea in semi-arid zones. Afr. Crop Sci. J. 9 (2) 359-367. https://doi org/10.4314/acsj.v9i2.27606

DADSON RB, HASHEM FM, JAVAID I, JOSHI J, ALLEN AL and DEVINE TE (2005) Effect of water stress on the yield of cowpea (Vigna unguiculata L. Walp.) genotypes in the Delmarva Region of the United States. J. Agron. Crop Sci. 191 210-217. https://doi. org/10.1111/j.1439-037X.2005.00155.x

DAFF (Department of Agriculture, Forestry and Fisheries, South Africa) (2014) Production guidelines for cowpeas. Department of Agriculture, Forestry and Fisheries, Pretoria, South Africa.

EHLERS JD and HALL AE (1997) Cowpea (Vigna unguiculata L. Walp.). Field Crops Research 53 187-204. https://doi.org/10.1016/ S0378-4290(97)00031-2

FALOYE OT and ALATISE MO (2017) Response of soil moisture content, evapotranspiration, and yield of cowpea to varying water application. Agric. Eng. Int. CIGR J. 19 (4) 66-75.

FAROOQ M, HUSSAIN M, WAHID A and SIDDIQUE KHM (2012) Drought stress in plants: an overview. in Aroca RS (ed) Plant Responses to Drought Stress: From Morphological to Molecular Features. Springer-Verlag, Berlin. 1-33. https://doi. org/10.1007/978-3-642-32653-0_1

FATHI A and TARI DB (2016) Effect of drought stress and its mechanism in plants. Int. J. Life Sci. 10 1-6. https://doi.org/10.3126/ ijls.v10i1.14509

FERERES E and SORIANO MA (2007) Deficit irrigation for reducing agricultural water use. J. Exp. Bot. 58 (2) 147-159. https://doi. org/10.1093/jxb/erl165

FIGUEIREDO MVB, BEZERRA-NETO E and BURITY HA (2001)
Water stress response on the enzymatic activity in cowpea nodules. Braz. J. Microbiol. 32 195-200. https://doi.org/10.1590/ S1517-83822001000300006

HAMIDOU F, ZOMBRE G and BRACONNIER S (2007) Physiological and biochemical responses of cowpea genotypes to water stress under glasshouse and field Conditions. J. Agron. Crop Sci. 193 229237. https://doi.org/10.1111/j.1439-037X.2007.00253.x

ILUNGA K (2014) Physiological responses of cowpea (Vigna unguiculata) to water stress under varying water regimes. Dissertation, University of KwaZulu-Natal.

ISHIYAKU MF, SINGH BB and CRAUFURD PQ (2005) Inheritance of time to flowering in cowpea (Vigna unguiculata (L.) Walp.). Euphytica 142 (3) 291-300. https://doi.org/10.1007/s10681-005-2435-0

KANDA EK, MABHAUDHI T and SENZANJE A (2018) Hydraulic and clogging characteristics of Moistube irrigation as influenced by water quality. J. Water Suppl. Res. Technol. 67 (5) 438-446. https:// doi.org/10.2166/aqua.2018.166

LYU W, NIU W, GU J, LI Y, ZOU X and ZHANG R (2016) Effects of moistube depth and density on tomato yield and quality in solar greenhouse. Chin. J. Eco-Agric. 24 (12) 1663-1673.

MALEKI A, ESNAASHAR N and BIDABADI AA (2017) Impact of deficit irrigation on yield components, water use efficiency and yield response factor of cowpea in Khorramabad Iran. J. Eng. Appl. Sci. 12 (9) 2471-2479.

MOUSA MAA and QURASHI ADA (2017) Growth and yield of cowpea (Vigna unguiculata L.) cultivars under water deficit at different growth stages. Legume Res. 40 (6) 1-8. https://doi.org/10.18805/ LR-384

NTOMBELA Z (2012) Growth and yield responses of cowpeas (Vigna unguiculata L.) to water stress and defoliation. Thesis, University of KwaZulu-Natal.

PEKSEN E (2007) Yield performance of cowpea cultivars (Vigna unguiculata (L.) Walp) under rainfed and irrigated conditions. Inter. J. Agric. Res. 2 (4) 391-396. https://doi.org/10.3923/ijar.2007.391.396

PRASAD PVV, STAGGENBORG SA and RISTIC Z (2008) Impacts of drought and/or heat stress on physiological, developmental, growth, and yield processes of crop plants. In: Ahuja LR, VR Reddy, SA Saseendran and Q Yus (eds) Advances in Agricultural Systems Modeling, Response of Crops to Limited Water: Understanding and Modeling Water Stress Effects on Plant Growth Processes. American Society of Agronomy, Crop Science Society of America and Soil Science Society of America, Wisconsin, USA. 301-355.

REINDERS F, VAN DER STOEP I, LECLER N, GREAVES K, VAHRMEIJER J, BENADÉ N, DU PLESSIS F, VAN HEERDEN P, STEYN J, GROVÉ B, JUMMAN A and ASCOUGH G (2010) Standards and guidelines for improved efficiency of irrigation water use from dam wall release to root zone application. WRC Report No. K5/1482/4. Water Research Commission, Pretoria.

SEBETHA ET, AYODELE VI, KUTU FR and MARIGA IK (2010) Yields and protein content of two cowpea varieties grown under different production practices in Limpopo province, South Africa. Afr. J. Biotechnol. 9 (5) 628-634. https://doi.org/10.5897/AJB09.1132

SHIRINGANI RP and SHIMELIS HA (2011) Yield response and stability among cowpea genotypes at three planting dates and test environments. Afr. J. Agric. Res. 6 (14) 3259-3263.

SINGH BB, AJEIGBE HA, TARAWALI SA, FERNANDEZ-RIVERA $S$ and ABUBAKAR $M$ (2003) Improving the production and utilization of cowpea as food and fodder. Field Crops Res. 84 169177. https://doi.org/10.1016/S0378-4290(03)00148-5

SOUZA PJDOP, FARIASVDS, LIMAMJA, RAMOSTFandSOUSA AML (2017) Cowpea leaf area, biomass production and productivity under different water regimes in Castanhal, Pará, Brazil. Revista Caatinga 30 (3) 748-759. https://doi.org/10.1590/1983-21252017v30n323rc

SPRENT JI, ODEE DW and DAKORA FD (2009) African legumes: a vital but under-utilized resource. J. Exp. Bot. 61 (5) 1257-1265. https://doi.org/10.1093/jxb/erp342

TIMKO MP and SINGH BB (2008) Cowpea, a multifunctional Legume. In: Moore $\mathrm{PH}$ and R Mings (eds) Genomics of Tropical Crop Plants. Springer, Berlin. 227-258. https://doi. org/10.1007/978-0-387-71219-2_10

VAN RENSBURG WJ, VORSTER IHJ, VAN ZIJL JJB and VENTER SL (2007) Conservation of African leafy vegetables in South Africa. Afr. J. Food Agric. Nutr. Dev. 7 (3\&4) 92-98. 
XUE W, NIU W, ZHANG Z and ZHANG K (2013) Effects of the tomato growth and water use efficiency in sunlight greenhouse by Moistube-irrigation. Agric. Res. Arid Areas 25 (6) 61-66.

YANG W, TIAN L, DU T, DING R and YANG Q (2008) Research prospect of the water-saving irrigation by semi-permeable film. $J$. Water Resour. Water Eng. 19 (6) 60-63.

YAO F, LIU H, LI Y, LIU F and YUAN N (2014) Research on ecophysiological parameters of navel orange under Moistubeirrigation. J. Nanchang College Water Conserv. Hydroelec. Power 33 (6) 11-14.

YIN Y, SHEN L, GUO Y and ZHANG C (2017) The effect of different Moistube spacing of alternate micro-irrigation on water spinach growth in greenhouse. Water Saving Irrig. 42 (9) 1-4.
ZHANG G, SHEN L and GUO Y (2016a) Experimental study on the growth status of cabbages in green house with Moistube irrigation technology. Water Saving Irrig. 41 (7) 6-8.

ZHANG J, NIU W, ZHANG L and SHI L (2012) Experimental study on characters of wetted soil in moistube irrigation. Sci. Soil Water Conserv. 10 (6) 32-38.

ZHANG M, NIU W, LU Z, LI Y, WANG J and QIU X (2017) Effect of Moistube-irrigation on crop yield and water use efficiency. Chin. J. Eco-Agric. 25 (11) 1671-1683.

ZHANG M, NIU W, XU J and LI Y (2016b) Influences of microirrigation and subsoiling before planting on enzyme activity in soil rhizosphere and summer maize yield. Chin. J. Appl. Ecol. 27 (6) 1925-1934. 